\title{
MAKSI FOR ICT-BASED ACCOUNTING LEARNING AT VOCATIONAL HIGH SCHOOLS
}

\author{
Vivi Pratiwi \\ Universitas Negeri Surabaya \\ Moh. Danang Bahtiar \\ Universitas Negeri Surabaya \\ Han Tantri Hardini \\ Universitas Negeri Surabaya
}

\begin{abstract}
This study aims to produce ICT-based learning media for Vocational High Schools (VHS) in the form of ICT-based accounting multimedia application, named "Multimedia Akuntansi" (MAKSI) on bank reconciliation material. The development of learning media is done because of the limited number of innovative learning media available for VHS students, especially in the accounting field. The condition is influential on the students' low level of understanding. This research was research and development using the ADDIE (Analysis, Design, Development, Implementation, Evaluation) model. The use of the ADDIE model is because the model is flexible, so it can be used for learning instrument development. At each phase of development, evaluation and revision were conducted so that the resulting product became a valid and reliable product. This development resulted in MAKSI proven to be suitable for use in accounting learning. The feasibility of MAKSI was evaluated from the average score of product feasibility validation from the material expert by $87 \%$, from the media expert of $96 \%$, and the result of the students' evaluation by $88.7 \%$. MAKSI can help the learning process more enjoyable so that the media is interesting and proven to improve students' understanding significantly. MAKSI can be a complement, alternative, and variation of learning media in VHS. This product can be operated via laptops/computers as well as smartphones through free downloads in Play Store. The utilization of MAKSI is in accordance with the curriculum demand on the utilization of ICT in the learning process to support independent and student-centered learning. Keywords: learning media, ICT, multimedia, vocational high school, accounting learning, accounting multimedia application
\end{abstract}

Permalink: http://dx.doi.org/10.21831/jpv.v9i2.26013

Contact Vivi Pratiwi

vivipratiwi@unesa.ac.id

Department of Accounting Education, Faculty of Economy, Universitas Negeri Surabaya

Jl. Ketintang No. 2, Ketintang, Kec. Gayungan, Kota Surabaya, Jawa Timur 60231, Indonesia 


\section{INTRODUCTION}

Currently, the use of Information and Communication Technologies (ICT) is deeply embedded in everyday activities and touches many areas of life, such as work-field, recreation, and learning (Yuen, Fox, Sun, \& Deng, 2009). The development of ICT usage is evident from the increasing number of internet users as technology develops (Dong, Chang, \& Fan, 2017). The impact of ICT advancement is the development of various technologies and supporting applications to facilitate human life activities, including learning activities in education. The success of learning depends heavily on the accuracy of teachers in utilizing technology to fit the learning objectives and particularly on creating meaningful learning for students (Wankel \& Blessinger, 2013). Thus, it is necessary to design learning by using technology to maximize student learning activities.

The use of ICT in education is suggested as it can make learning more relevant and effective (Kang, Kim, \& Heo, 2011; Pate, 2016). The utilization of ICT in education has received much attention in the educational literature as a medium of learning and a strategy to address global challenges and provide a handson learning experience for students (Dawson, Heathcote, \& Poole, 2010). Learning media is a means or educational tool that can be used as an intermediary in the learning process to enhance effectiveness and efficiency in achieving learning objectives (Sanaky, 2013). In addition, learning media can provide variation in learning that is focused on not only teacher explanations, but opportunities for learning activities that enable students to be active in learning. Therefore, media can help teachers and students actively engage in two-way communication (Indriastoro \& Rofiq, 2014, p. 210). The use of technology in some media can support collaborative activities between teachers and students so that students can be more active and interactive in the learning process (Pratiwi, Siswandari, \& Santosa, 2018, p. 153; Susanti, Murtini, \& Harini, 2018, p. 303).

The benefits of ICT in education have influenced many countries to apply it in education to address global challenges (BuabengAndoh, 2015), including Vocational High Schools (VHS or Sekolah Menengah Kejuruan $(\mathrm{SMK})$ ) in Indonesia. VHS is a secondary education that prepares students primarily to work in a particular field. Learning in VHS is a combination of theory and practice from the departments the students choose. These areas of expertise must be deeply understood by the students. One department available in VHS is accounting. However, so far, the availability of media used to help the process of learning and understanding of students in VHS is still limited. Textbooks that support the subject of expertise are not too much found. Learning becomes focused on teacher explanations, so students cannot learn independently, whereas the curriculum requires creative, innovative, fun, and student-centered rather than teacher-centered learning. Moreover, the Directorate of Vocational High School Development (Direktorat Pembinaan SMK) continues to work hard to socialize the use of the internet for VHS through education and training, workshops for teachers and provision of infrastructure, so that the use of the internet is expected to be widely used in the field of education, especially in VHS (Arnanto \& Triyono, 2014, p. 320).

These conditions affect the students' low level of understanding and learning outcomes. Without the proper use of instructional media, students' knowledge will be more abstract. They only know that without understanding the material taught (Arsyad, 2013). The selection and design of appropriate learning media can improve students' ability to understand difficult principles, concepts, and procedures in accounting (Sithole, 2017). The demands and availability of existing technology should also be taken into consideration in designing appropriate learning for students. Thus, one of the proper ways to improve students' understanding is using innovative ICT-assisted learning (Butler \& Reddy, 2010). One of the various ICT-based learning media is an interactive multimedia application that can be used as an easy-to-understand learning alternative for students (Adedokun-Shittu \& Shittu, 2015; Trieb, 2016).

Multimedia has the potential to be used in many situations, such as showing the process in action or increasing the opportunity for students to interact with learning materials which are set realistically according to real conditions (Oud, 2009). Moreover, multimedia is a combination of several learning media that combine text, graphics, sound, animation, and video that together display information as a whole (Kulasekara, Jayatilleke, \& Coomaraswamy, 
2008). If multimedia is designed in an integrated, purposeful, and meaningful way in a particular material context, it can be a powerful medium for increasing student engagement in learning. Multimedia provides opportunities for active student-centered learning, in which students can choose the relevant words and images that can change their learning styles (Piyayodilokchai, Panjaburee, Laosinchai, Ketpichainarong, \& Ruenwongsa, 2013).

Based on these conditions, it is necessary to develop accounting learning media in the form of accounting multimedia, which is a combination of various forms of technologybased learning media to support the learning process by emphasizing the process of solving problems scientifically. The material used as the content of ICT-based accounting multimedia application is bank reconciliation. The material was chosen because students stated that the bank reconciliation material was difficult to understand. The development of this media is expected to make students motivated to seek information and communicate actively so they can conclude the material they learn by themselves. Multimedia is an appropriate tool, enables students to engage in learning actively, facilitates them in learning, as well as enables them to make decisions or take active action involving them in the learning process (ArenasMárquez, Machuca, \& Medina-López, 2012). The use of multimedia in learning will make students more interested in participating in the teaching and learning process because the material contained in multimedia learning is made as attractive as possible and inserted with animations that support the material (Admadja \& Marpanaji, 2016, p. 175). Therefore, this study aims to produce ICT-based learning media for VHS in the form of ICT-based accounting multimedia application (MAKSI) on bank reconciliation material.

\section{RESEARCH METHOD}

This research is research and development in education. Research and development is a research method used to develop or validate products used in education and learning (Gall, Gall, \& Borg, 2003). The development model used in this research is the ADDIE model consisting of five phases: Analysis, Design, Develop, Implementation, and Evaluation developed by Reiser and Mollenda (Pribadi,
2010, p. 115). The researchers employed the model because the model is general and flexible, so it can be used for learning instrument development. At each phase of development, evaluation and revision were conducted so that the resulting product became valid and reliable.

The development of ICT-based accounting multimedia (MAKSI) on bank reconciliation material is a series of processes undertaken to develop a new product in instructional media based on the existing development theory. In this research, the developed product and its feasibility were tested based on the validation of the experts and the students. In addition to developing and validating learning media, this research also aims to solve learning problems and find the knowledge that can be used as practical solutions. The outcomes of this research are expected to be ICT-based learning media solution that is used not only by the target schools but also by those all over Indonesia through application downloads in the Android Play Store. The research and development procedure of MAKSI is illustrated in Figure 1.

\section{Analysis Phase}

The analysis phase begins with information-gathering activity and learning problem identification to serve as a basis for developing new products. This phase includes the implementation of performance and needs analyses used to formulate learning objectives. Performance analysis aims to define the circumstances occurring in the field and to clarify what performance problems are encountered. At this phase, an observation is made to identify the gap between the current learning conditions and the desired learning conditions related to the students' understanding of the learning materials. The observations were conducted at SMK Negeri 1 Surabaya, Indonesia, a vocational high school that has an accounting department. Based on the results of the performance analysis, needs analysis was then conducted for product development. At this phase, an analysis of the material was carried out in the development of the bank reconciliation material. Then, the researchers determined the learning objectives based on the results of needs analysis. 


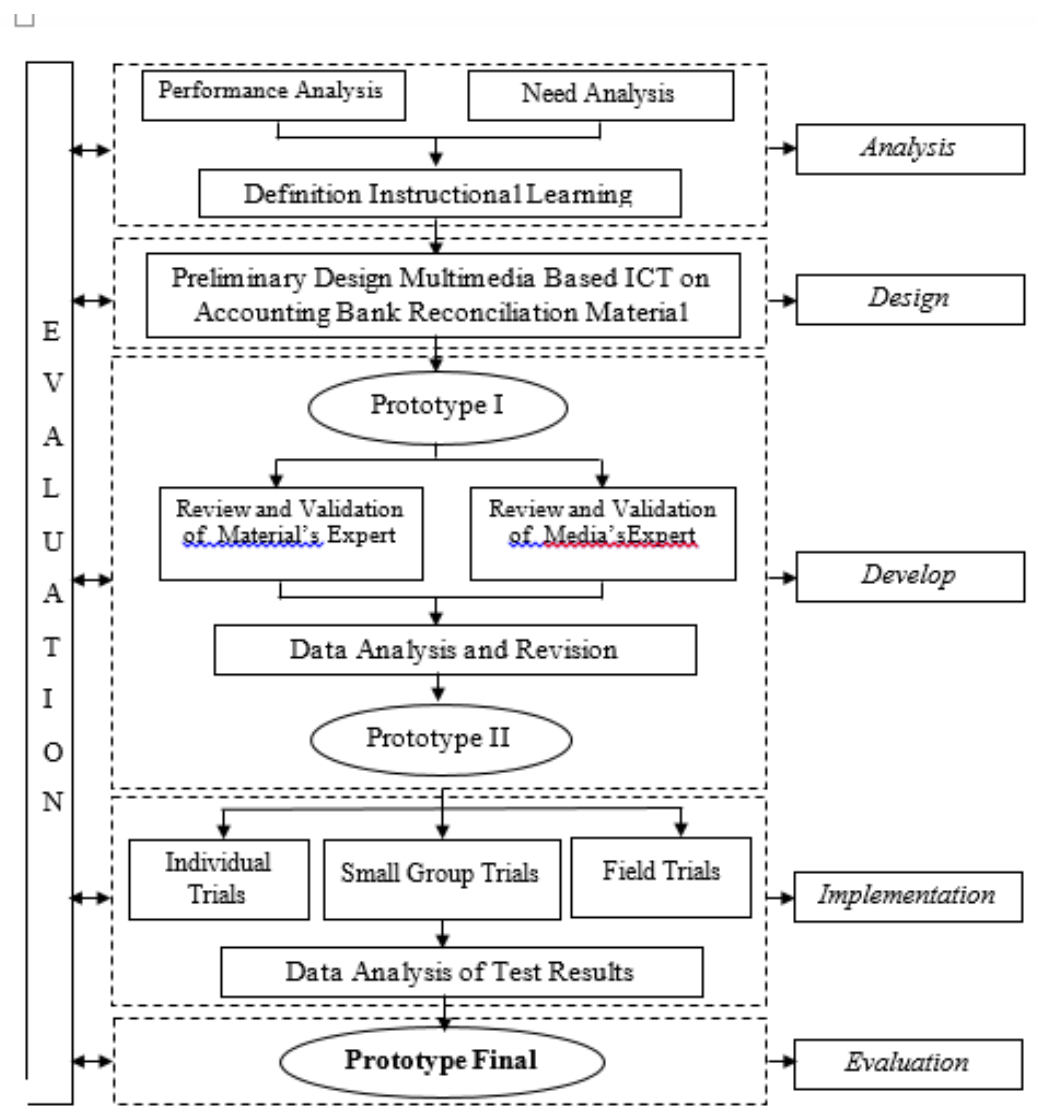

Figure 1. Development Framework Model of MAKSI

\section{Design Phase}

Design phase is done to facilitate the design of products to be developed in the form of a solution to the problem that has been described in the analysis phase, which consists of pre-production and storyboard preparation phases. Pre-production activities begin with designing the contents of the developed product that is the material and presentation appropriate to the learning objectives. Then, the concept of the developed accounting multimedia is set up. The components needed in the development are also prepared in this phase, such as creating animated figures in accounting multimedia, background design, preparing audio, and other visual and audio components needed for product development. MAKSI was created using Adobe Flash Professional software. The next step is making the learning media storyboard in the form of a product development program script.

\section{Development Phase}

The development phase is the realization of the development plan in the designing phase that aims to produce product development whose validity, feasibility, and effectiveness furthermore need to be tested This phase consists of production activities as well as product review and validation. Production activities were based on a storyboard that has been created at the design phase so as to produce the initial product of MAKSI (Prototype I). Next, Prototype I was validated by the experts, consisting of material and media experts. From the results of experts' validations, opinions, and suggestions for improvement of product development were obtained. The next revision of Prototype I was in accordance with the opinions and suggestions of improvement from the experts. The revised Prototype I was then revalidated by the expert to provide a media feasibility assessment. This phase resulted in MAKSI ready for trials (Prototype II).

\section{Implementation Phase}

This phase is a pilot phase, in which MAKSI product that has been reviewed and validated (Prototype II) was tested on the individual, small group, and field trials. The 
trial was conducted on the eleventh students of the accounting department in SMK Negeri 1 Surabaya, Indonesia. The population in this study was all eleventh students of the accounting department in SMK Negeri 1 Surabaya amounted to 252 people divided into six classes. The sampling technique in selecting the class used in individual, small group and field trials was simple random sampling because all students in the population received the same material with the same methods, learning media, and curriculum so that the population is considered homogeneous.

The individual trial was conducted on three selected students with high, medium, and low ability so that they can be viewed as representative samples. This trial was conducted to obtain evidence of the initial product (Prototype II) feasibility on a limited basis emphasizing the suggestions and feedback on the product from the students as the users to be taken into consideration in revising the product. The revised Prototype II was based on the experts' opinions and suggestions, and three students proceeded to the small group trial phase. At this phase, the product was tested on a small group of students consisting of ten not included in the individual trial. This trial aims to obtain product feasibility data from the students as users. Based on the results of the trial, the ICT-based accounting multimedia was appropriate for use in the field test for product effectiveness test. The field test is a test conducted in the field with a minimum sample size of 30 people. Therefore, a well-tested Prototype II of small group trial results was tested on 40 students to determine the effectiveness of the developed products. The effectiveness test of the product use was done by giving pre-test and post-test in the form of an essay test about bank reconciliation material.

\section{Evaluation Phase}

This phase aims to assess whether the product developed in accordance with expectations or not. In the ADDIE development model, the evaluation phase is not only at the end of the development but also at each phase. The evaluation is needed for revision needs or formative evaluation. From the evaluation phase, it was found that the final product of ICT-based accounting multimedia tested was feasible and ready to be used in the accounting learning process on bank reconciliation material.

The types of data obtained in this research are qualitative and quantitative data. The data collection techniques used in this research are observation, interview, questionnaire, and test. The form of the test used in this study is the test of learning outcome in the form of an essay test which is aimed at revealing the data of students' understanding of bank reconciliation material. MAKSI is considered feasible if the average result of all aspects in the expert validation questionnaire and the students' assessment gets a percentage of $\geq 61 \%$ to obtain a feasible or very feasible interpretation (Riduwan, 2013). Pre-test and post-test results were calculated using a t-test to determine whether there was an increase in the students' scores after using MAKSI.

\section{RESULTS AND DISCUSSION}

The results of MAKSI development research on bank reconciliation material were based on the development process, feasibility, and effectiveness of the media through five phases of the ADDIE model, namely: Analysis, Design, Development, Implementation, and Evaluation phase. The results of the study can be explained as follows:

\section{Analysis Phase}

From the analysis phase, it was obtained that the appropriate school for the research was SMK Negeri 1 Surabaya, which is the best vocational high school in Surabaya, Indonesia, and has an accounting department. The school already has enough facilities in the form of a computer lab, free-wifi, and LCD-projector provided in each class. With such conditions, ICT-based learning is feasible because the facilities are adequate. Then, the observation and interview with students about the condition of perceived learning were conducted. The students said that one of the difficult accounting materials was bank reconciliation material. It was found that the students had difficulties in understanding the terms of the bank reconciliation because they were only given knowledge of the theories, which led to the differences in bank reconciliation. It made them just memorizing without really understanding where the differences in bank reconciliation that should be recorded in the company report or bank 
statements are from. They also expressed the need for the development of instructional media used. They felt that the learning was monotonous and boring because almost all subjects only used textbooks and sometimes only relied on the teachers' explanations.

Based on the results of the above performance analysis, it indicates that there are problems in learning accounting, especially on bank reconciliation material. The problem lay in the limited learning media used in accounting learning so that the students' understanding of bank reconciliation material was still low. The selection of instructional media in the form of textbooks had not been optimal because the school facilities are complete, and ICT-based facilities are available. It also made the students get tired and feel that learning is not so interesting that they tend to be passive, and the learning is teacher-centered. In addition, the demands of the curriculum and the development of the era associated with the use of ICT in the learning process need to be considered. With these conditions, it is necessary to improve accounting learning with the selection of appropriate learning media to improve students' understanding by utilizing ICT.

The development of ICT-based learning media is a form of ICT utilization in learning. One of ICT-based learning media is interactive multimedia that can be used in on-line/off-line learning. Multimedia provides many benefits in learning. It makes the material closer to real conditions (Oud, 2009); it creates active, student-centered learning (Piyayodilokchai et al., 2013), fun, and also exciting learning (Téllez, 2008); and improves students' understanding in accounting learning (Sithole, 2017). Therefore, ICT-based multimedia is an appropriate learning medium to be developed based on the problems encountered.

\section{Design Phase}

The product was designed with the concept of responsive design, meaning that the developed accounting multimedia display fits in various media, such as smartphones, computers, and laptops. The application used for making the product was Adobe Flash Professional, so that the output file format is adapted to the media used. For Android-based mobile phones (smartphones), it uses .apk format so it can be downloaded in the Android Play Store. For computers and laptops, the format is .swf.
Thus, the developed product was accessible either by teachers or students according to the devices they have. Then the presentation of ICT-based accounting multimedia as outlined in the storyboard in the form of a script program was made. The program script consists of the content displayed in each scene consisting of the opening, content, and closing sections. Furthermore, the making of animated characters in multimedia accounting, background design, music accompaniment (audio), and other visual and audio components is also prepared at this stage. In the end, the name of the product was developed, namely ICT-Based Accounting Multimedia (MAKSI).

\section{Development Phase}

Development phase consists of production activities as well as a product review and validation activities. Production activities were done based on the program script (storyboard) previously made. This production activity produced the initial product of MAKSI (Prototype I) presented in Figure 2.

The Prototype I was reviewed and validated by the experts of materials and media. The validation resulted in suggestions and also feedbacks consisting of: (1) back sound variation, (2) the addition of the narrative material, (3) the arrangement of the narrator and back sound volume so as not to collide, (4) the clarification of the instructions for use in each section. Based on these suggestions, improvements were made to produce a revised Prototype I and then validated by the experts. Material expert validation results are depicted in Figure 3.

Figure 3 shows that the accuracy of MAKSI is $90 \%$ of feasibility, which means that MAKSI has clearly defined learning objectives and materials. Similarly, the aspect of interest shows the percentage of the feasibility of $90 \%$, which means that the concept developed in ICT-based accounting multimedia allows students to understand bank reconciliation material. The completeness aspect obtains a $90 \%$ of feasibility, which means that the bank reconciliation material contained in MAKSI is presented in an actual, complete, logical, clear, and coherent manner. The material delivered is also packaged in an interesting and related to the knowledge that students have so that the aspect of attention obtains a percentage of the feasibility of $90 \%$. MAKSI also has good con- 


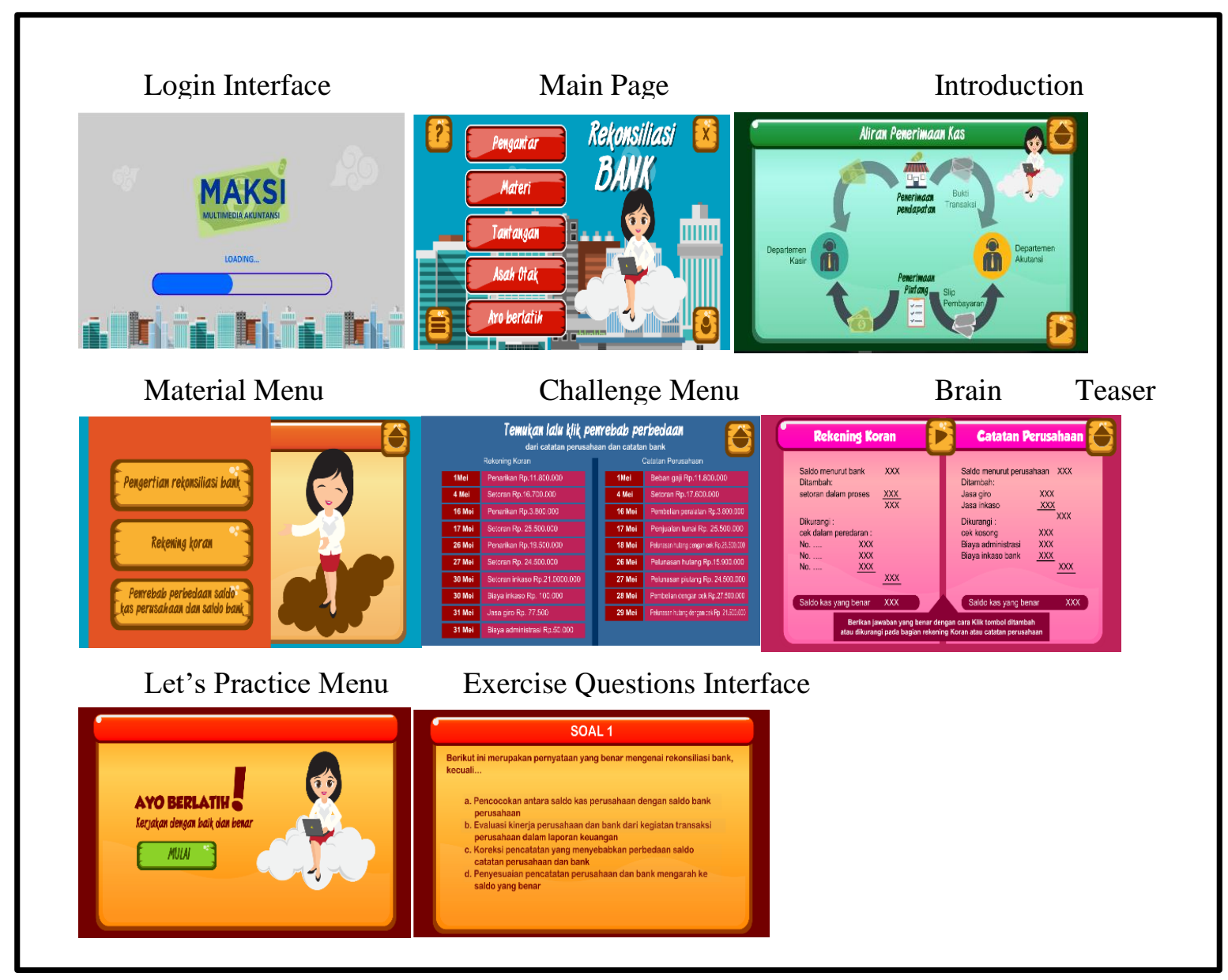

Figure 2. MAKSI Features and Interface

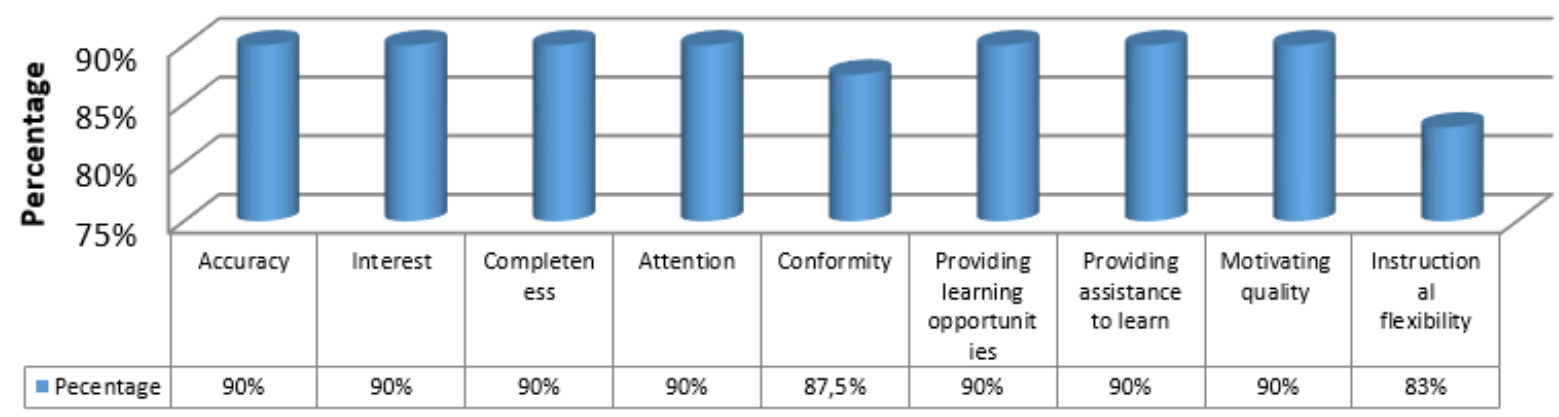

Figure 3. Feasibilty of MAKSI from Material

formity so as to obtain the percentage of the feasibility of $87.5 \%$. On the aspect of providing learning opportunities, the feasibility is $90 \%$, which means that MAKSI was also proven to provide learning opportunities for students to develop knowledge independently and equipped with simulation on bank reconciliation exercises. MAKSI provides solutions and assistance to improve students' understanding because the design and illustrations used to make it easier for students to learn bank reconcili- ation material so that the aspect of providing assistance to learn gets a $90 \%$ percentage of feasibility. Then the aspect of motivating quality gets $83 \%$ feasibility percentage which means that the presentation of material concept in MAKSI cultivates students' curiosity, creativity, liveliness, and learning motivation. It is evident from the change in the students' attitudes when using MAKSI to be more active in asking questions and more diligent when working on questions and exercises provided. The bank re- 
conciliation material presented in MAKSI can also be reused in the next school year so that the instructional flexibility aspect gets an $80 \%$ percentage of feasibility.

Based on the validation score from those some aspects, it was obtained the average score of MAKSI feasibility by the material expert is $87 \%$, which is included in the category of "Very Eligible". Thus, it can be concluded that in terms of material conformity, MAKSI is very suitable to be used as a medium of learning on bank reconciliation material. Then, the validation of media experts to the feasibility of MAKSI can be described in Figure 4.

The percentage of the readability aspect is $100 \%$, which means that the selection of letters, models, sizes, colors, the layout of text, and the use of language is appropriate so that it can be read very well by the users. MAKSI is also very easy to use, evident from the feasibility percentage in the aspect of ease of use of $100 \%$. MAKSI is easy to use because it provides instructions for the use of media and can run on a variety of hardware specifications, laptops/computers, and android-based smartphones. MAKSI is also packed with an eyecatching look on each page by considering color and background alignment, text and image layout, music illustrations and sound effects, and the use of animations that are appealing and tailored to the students' age. Therefore, the aspect of display quality obtains a feasibility percentage of $95 \%$. MAKSI program quality obtains a percentage of the feasibility of $100 \%$, which means the selection of media and applications developed is appropriate and in accordance with the times. MAKSI file is not large and simple in operation so that it is effective and efficient to develop and use the availability of navigation, clear instructions, and feedbacks for the users in every menu contained in MAKSI also maximize the quality of the developed media. Based on the results of the validation of media experts on the four aspects above, MAKSI obtains an average percentage of $96 \%$. It can be concluded that the development of MAKSI is very feasible to be used as an ICTbased accounting learning media.

\section{Implementation Phase}

After obtaining validation from material and media experts, the product was tested to find out the students' opinions and assessments as MAKSI users. From the product testing on the individual trial conducted on three students, it was suggested that the number of questions provided on the let's practice! menu should be increased. Based on these suggestions, there were additional questions, as many as 20 multiple-choice questions greater than the initial questions of ten multiple-choice questions. Then, the small-group trial was conducted on ten students to find out the feasibility of ICTbased accounting multimedia from the students as the users. They were asked to try to use ICTbased accounting multimedia then fill out student assessment questionnaires. MAKSI feasibility assessment from the students as the users can be described in Figure 5.

Based on the students' assessment of MAKSI, the average percentage of feasibility is $88.7 \%$, which indicates that three aspects assessed in MAKSI, i.e., the quality of content and objectives, instructional quality, and technical quality, get excellent responses from the students. According to the students' opinions, the presentation of bank reconciliation material in MAKSI is good and complete in accordance with the material contained in textbooks that they normally use. The material contained in MAKSI is also in accordance with the learning objectives of the financial accounting subject.

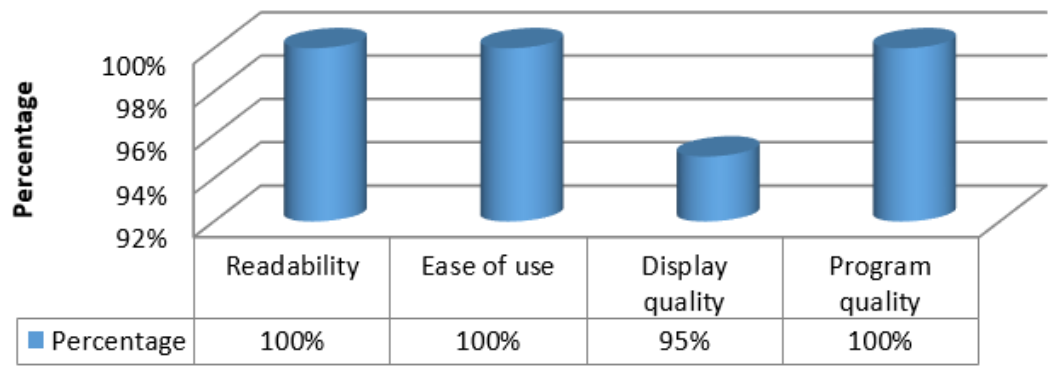

Figure 4. Feasibilty of MAKSI from Media Expert 


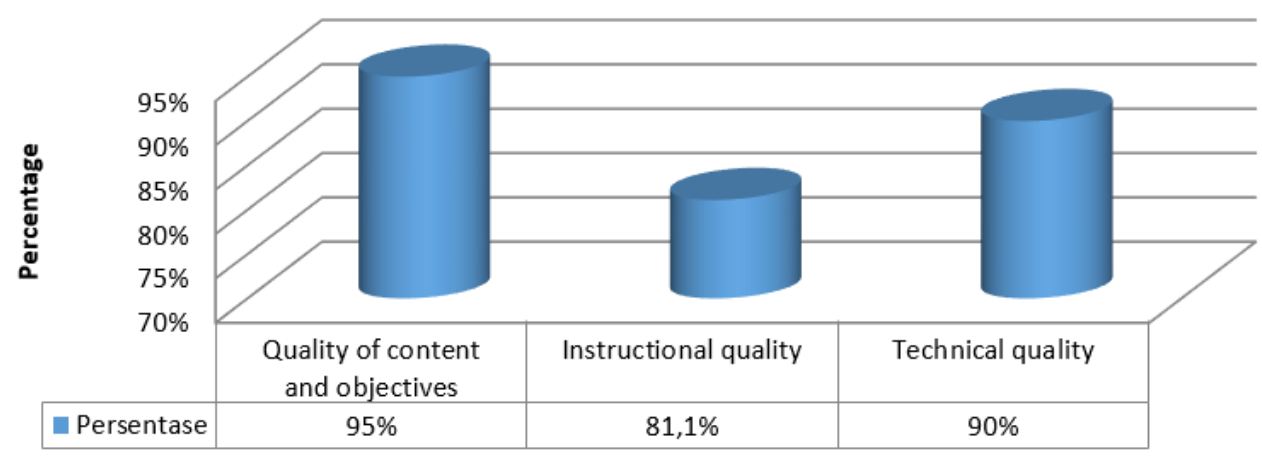

Figure 5. Feasibilty of MAKSI from Students' Assesment

Therefore, the feasibility of content and objective quality aspect is $95 \%$. The students thought that the use of MAKSI did not interfere with learning and even made them learn more and understand the bank reconciliation material more deeply. The use of MAKSI made learning more enjoyable so that students paid more attention to the lesson. Although they felt that they would not often use MAKSI because the material is still limited to bank reconciliation, the students thought that many people would learn faster with the help of MAKSI. Therefore, the aspect of instructional quality obtained a feasibility percentage of $81.1 \%$. In the technical aspect, the percentage of feasibility is $90 \%$. Students felt the language used was appropriate so that they more easily understood the material after learning with MAKSI.

A further field trial was conducted to determine the effectiveness of ICT-based accounting multimedia to improve students' understanding of bank reconciliation material. The test was performed on 40 students by giving pre-test and post-test. The differences in the students' understanding were analyzed using the t-test. The test results are presented in Table 1, which indicates that there are significant differences in students' understanding between pre-test and post-test $(\mathrm{p}=.000)$.

Table 1.Pre-test and Post-test Score

\begin{tabular}{lcccccc}
\hline & n & Mean & sd & df & t & p \\
\hline Pre-test & 40 & 52.18 & 9.235 & & & \\
Post-test & 40 & 76.23 & 12.624 & & & \\
\hline
\end{tabular}

Source: The data process in 2018

Based on Table 1, it can be seen that the significance value of the t-test is 0.00 . The significance value is smaller than $0.05(0.00$
$<0.05$ ), so that it can be stated that there is a difference between students' understanding before and after using MAKSI. These results indicate that in general, after using MAKSI, learning can increase students' understanding (Pratiwi et al., 2018, p. 151).

\section{Evaluation Phase}

The results of the overall validation score analysis obtains a score of $90.6 \%$. It indicates that the MAKSI on bank reconciliation material is considered very feasible to be used in learning with average material expert validation of $87 \%$. The average validation from the media expert is $96 \%$, and the student's average assessment is $88.7 \%$. Thus, it was found that the use of MAKSI can help the learning process to become more fun and improve students' understanding because it is easy to use and interesting for students. MAKSI has complete features/menu ranging from introductory material, core material, simulation, and practice questions that can be operated on laptops/ computers and smartphones. The use of this medium was also able to make students more active and curious so that they were motivated to learn independently. The test results also show that after using MAKSI, the students' understanding increases. This is evidenced by the increase in the average students' test scores from 52.18 (pre-test) to 76.23 (post-test).

The results of this discussion indicate that multimedia applications and practical experience can deepen students' abilities and knowledge and increase student motivation (Adedokun-Shittu \& Shittu, 2015, p. 191; Nickchen \& Mertsching, 2016, p. 482; Scott \& Cong, 2010, p. 280; Trieb, 2016, p. 310; Wankel \& Blessinger, 2013, p. 7). Students' understanding can also be developed by using 
innovative, interesting, and fun learning with the help of ICT (Butler \& Reddy, 2010, p. 772; Lindberg, Olofsson, \& Fransson, 2017, p. 126; Zweekhorst \& Maas, 2015, p. 15). In addition, the opinion of Riduwan (2013, p. 89) states MAKSI in the material of bank reconciliation can be said to be feasible if the average percentage of questionnaires validated by material experts and media experts as well as student evaluations averaged $61 \%$. Based on the results of the research and the data obtained in the field, it can be stated that MAKSI is proven to be very feasible to use in accounting learning. Therefore, MAKSI is expected to be a fun alternative learning media and to improve students' understanding.

\section{CONCLUSION}

This research and development resulted in the form of ICT-based accounting multimedia (MAKSI) on bank reconciliation material suitable for use in accounting learning in vocational high schools. The development process conforms to the ADDIE development model through five stages of development consisting of analysis, designing, development, implementation, and evaluation stage. Based on the validation of material and media experts, ICTbased accounting multimedia on bank reconciliation material is very feasible to be used as a medium of learning with the average validation score from the material experts by $87 \%$ and the average validation score from the media expert of $96 \%$. In respect to the result of the assessment of students as the users, ICT-based accounting multimedia on bank reconciliation material is very feasible to use as a medium of learning indicated by the average percentage of students' assessment of $88.7 \%$.

The utilization of MAKSI in learning can increase the average students' score. Before using ICT-based accounting multimedia (pretest), the average score was 52.18, and after using ICT-based multimedia accounting (posttest), the score increased to 76.23. Hence, it can be concluded that the average score after using ICT-based accounting multimedia (post-test) is better than that before using the application. The results are consistent with those of Trieb (2016), Adedokun-Shittu and Shittu (2015), and Sithole (2017) studies which stated that a multimedia is a tool that enables students to engage in learning actively, facilitates learn- ing, and enables them to make decisions or take active action involving them in the learning process. Multimedia applications and practical experience can deepen the students' ability and understanding, as well as increase their motivation (Butler \& Reddy, 2010; Nickchen \& Mertsching, 2016).

\section{REFERENCES}

Adedokun-Shittu, N. A., \& Shittu, A. J. K. (2015). Assessing the impacts of ICT deployment in teaching and learning in higher education: Using ICT impact assessment model. Journal of Applied Research in Higher Education, 7(2), 180-193. https://doi.org/10.1108/JARH E-02-2013-0012

Admadja, I. P., \& Marpanaji, E. (2016). Pengembangan multimedia pembelajaran praktik individu instrumen pokok dasar siswa SMK di bidang keahlian karawitan. Jurnal Pendidikan Vokasi, 6(2), 173-183. https://doi.org/10.21831/jpv.v6i2.8107

Arenas-Márquez, F. J., Machuca, J. A. D., \& Medina-López, C. (2012). Interactive learning in operations management higher education. International Journal of Operations \& Production Management, 32(12), 1395-1426. https://doi.org/10.1108/0144357121128 4160

Arnanto, G. C., \& Triyono, M. B. (2014). Keefektifan pembelajaran berbantuan internet di SMK se-Kota Yogyakarta kompetensi keahlian teknik komputer dan jaringan. Jurnal Pendidikan Vokasi, 4(3), 318-332. https://doi.org/10.21831/ jpv.v4i3.2557

Arsyad, A. (2013). Media pembelajaran. Jakarta: PT. Raja Grafindo Persada.

Buabeng-Andoh, C. (2015). ICT usage in Ghanaian secondary schools: Teachers' perspectives. International Journal of Information and Learning Technology, 32(5), 1-15. https://doi.org/10.1108/ IJILT-09-2015-0022

Butler, M. J. R., \& Reddy, P. (2010). Developing critical understanding in HRM students. Journal of European 
Industrial Training, 34(8/9), 772-789. https://doi.org/10.1108/0309059101108 0968

Dawson, S., Heathcote, L., \& Poole, G. (2010). Harnessing ICT potential. International Journal of Educational Management, 24(2), 116-128. https://doi.org/10.1108/ 09513541011020936

Dong, X., Chang, Y., \& Fan, X. (2017). Effects of the characteristics of online multimedia synergy on consumers' message acceptance and message response. Online Information Review, 41(5), 710-727. https://doi.org/10.1108/ OIR-11-2016-0328

Gall, M. D., Gall, J. P., \& Borg, W. R. (2003). Educational research. Boston, MA: Pearson Education.

Indriastoro, H. A. K., \& Rofiq, Z. (2014). Pengembangan multimedia pembelajaran pada standar kompetensi memperbarui halaman web di SMK. Jurnal Pendidikan Vokasi, 4(2), 208221. https://doi.org/10.21831/jpv.v4i2. 2546

Kang, M., Kim, M., \& Heo, H. (2011). The impact of ICT use on new millennium learners' educational performance. Interactive Technology and Smart Education, 8(1), 18-27. https://doi.org/ $10.1108 / 17415651111125487$

Kulasekara, G. U., Jayatilleke, B. G., \& Coomaraswamy, U. (2008). Designing interface for interactive multimedia: Learner perceptions on the design features. Asian Association of Open Universities Journal, 3(2), 83-98. https://doi.org/10.1108/AAOUJ-03-022008-B002

Lindberg, O. J., Olofsson, A. D., \& Fransson, G. (2017). Same but different? An examination of Swedish upper secondary school teachers' and students' views and use of ICT in education. International Journal of Information and Learning Technology, 34(2), 122132. https://doi.org/10.1108/IJILT-092016-0043

Nickchen, D., \& Mertsching, B. (2016). Combining mathematical revision courses with hands-on approaches for engineering education using web-based interactive multimedia applications. Procedia - Social and Behavioral Sciences, 228, 482-488. https://doi.org/ 10.1016/j.sbspro.2016.07.074

Oud, J. (2009). Guidelines for effective online instruction using multimedia screencasts. Reference Services Review, 37(2), 164-177. https://doi.org/10.1108/ 00907320910957206

Pate, L. P. (2016). Technology implementation: impact on students' perception and mindset. International Journal of Information and Learning Technology, 33(2), 91-98. https:// doi.org/10.1108/IJILT-10-2015-0033

Piyayodilokchai, H., Panjaburee, P., Laosinchai, P., Ketpichainarong, W., \& Ruenwongsa, P. (2013). A 5E learning cycle approach-based, multimediasupplemented instructional unit for structured query language. Journal Educational Technology and Society, 16(4), 146-159.

Pratiwi, V., Siswandari, S., \& Santosa, D. (2018). Students' understanding through the use of ICT-based accounting multimedia (MAKSI) in vocational high schools. Jurnal Pendidikan Vokasi, 8(2), 151-162. https://doi.org/10.21831/jpv. v8i2.19450

Pribadi, B. A. (2010). Model desain sistem pembelajaran. Jakarta: Dian Rakyat.

Riduwan. (2013). Skala pengukuran variabelvariabel penelitian. Bandung: Alfabeta.

Sanaky, H. A. H. (2013). Media pembelajaran interaktif-inovatif. Yogyakarta: Kaukaban Dipantara.

Scott, B., \& Cong, C. (2010). Evaluating course design principles for multimedia learning materials. Campus-Wide Information Systems, 27(5), 280-292. https://doi.org/10.1108/1065074101108 7720

Sithole, S. T. M. (2017). Enhancing students understanding of introductory accounting by integrating split-attention instructional material. Accounting Research Journal, 30(3), 283-300. 
https://doi.org/10.1108/ARJ-08-20150104

Susanti, A., Murtini, W., \& Harini, H. (2018). Development of web-based interactive multimedia for human-resourcemanagement learning in Vocational High Schools. Jurnal Pendidikan Vokasi, 8(3), 300-312. https://doi.org/ $10.21831 / j p v . v 8 i 3.20364$

Téllez, A. G. (2008). Authoring multimedia learning material using open standards and free software. Interactive Technology and Smart Education, 4(4), 192-199. https://doi.org/10.1108/17415 650880001104

Trieb, C.-A. (2016). Application of learning technologies to promote holistic thinking and consensus building in global studies. International Journal of Information and Learning Technology, 33(5), 300-314. https://doi.org/10.1108/ IJILT-01-2016-0005
Wankel, L. A., \& Blessinger, P. (2013). Inventive approaches in higher education: An introduction to using multimedia technologies. Cutting-Edge Technologies in Higher Education, 6(PART F), 3-16. https://doi.org/10. 1108/S2044-9968(2013)000006F003

Yuen, A., Fox, R., Sun, A., \& Deng, L. (2009). Course management systems in higher education: Understanding student experiences. Interactive Technology and Smart Education, 6(3), 189-205. https:// doi.org/10.1108/17415650911005393

Zweekhorst, M. B. M., \& Maas, J. (2015). ICT in higher education: Students perceive increased engagement. Journal of Applied Research in Higher Education, 7(1), 2-18. https://doi.org/10.1108/ JARHE-02-2014-0022 